\title{
SOSIALISASI DAN PELATIHAN PEMBUATAN MAKANAN HERBAL SEBAGAI UPAYA PENGEMBANGAN SUMBER DAYA MANUSIA DESA BRUMBUN
}

\author{
Aziz Rivai ${ }^{1}$, Ajeng Wahyuni ${ }^{2}$ \\ 1,2Institut Agama Islam Negeri Ponorogo \\ 1E-mail address azizrivai26@gmail.com; 2 E-mail address ajeng@iainponorogo.ac.id
}

\begin{abstract}
Brumbun village is a village located in Wungu sub-district, Madiun district, where the village is located at the eastern end near the slopes of the mountains of Madiun City. The place is still beautiful and is flanked by two streams of water originating from the mountains and has a very open, skilled community, accepts input and likes to work together. making this place rich in potential assets. Its abundant and unspoiled natural wealth makes this village dubbed a tourist village that is visited for family vacations and learning facilities. There are many plants that thrive in the village, including those with herbal nuances. Based on the survey, it was found that herbal plants such as moringa leaves and katuk leaves were unfortunately left unattended. Villagers only cultivate plants that are easy to process, such as cassava, tales and rice. Departing from personal assets and the many herbal plants that grow in the village as well as encouragement from the village government. So, the need for training on the manufacture of this herbal food is done. After the training was carried out, the response was positive and the enthusiasm of the PKK women showed that the training was very acceptable, the enthusiasm of the PKK women in the training made the training event run smoothly from start to finish. The evaluation results show that PKK mothers are able to do well. Even so, there is still a need for more assistance related to how to get perfect results and have a selling point.
\end{abstract}

Keywords: Training, Herbal Food, Human Resources

\begin{abstract}
Abstrak
Desa Brumbun adalah desa yang terletak di Kecamatan Wungu, Kabupaten Madiun yang dimana desa tersebut terletak di ujung timur dekat lereng pegunungan Kota Madiun. Tempatnya yang masih asri dan dihampit dua aliran sumber air yang berasal dari pegunungan serta memiliki masyarakat yang sangat terbuka, terampil, menerima masukan dan suka bergotong royong. menjadikan tempat ini kaya akan aset potensial. Kekayaan alamnya yang melimpah dan masih alami menjadikan Desa ini dijuluki sebagai Desa Wisata yang dikunjungi untuk tempat liburan keluarga dan sarana belajar. banyak tanaman yang tumbuh subur didesa tersebut, tidak terkecuali tanaman yang bernuansa herbal. Berdasarkan survei ditemukan
\end{abstract}


tanaman herbal seperti Daun Kelor dan Daun Katuk yang disayangkan dibiarkan begitu saja. Masyarakat desa hanya mengolah tanaman yang dirasa mudah untuk diolah seperti Ketela, Tales dan Padi. Berangkat dari aset personal dan banyaknya tanaman herbal yang tumbuh didesa serta dorongan dari pihak Pemerintah Desa untuk memanfaatkannya. Maka, perlunya pelatihan mengenai pembuatan makanan herbal ini dilakukan. Setelah pelatihan dilakukan respon yang positif dan antusiasme ibu-ibu PKK menunjukkan sangat diterimannya pelatihan ini, semangatnya ibu-ibu PKK dalam pelatihan menjadikan acara pelatihan lancar dari awal hingga akhir. Hasil evaluasi menunjukka ibu-ibu PKK mampu melakukan dengan baik. meskipun seperti itu masih perlunya pendampingan lebih terkait bagaimana agar dapat hasil yang sempurna dan memiliki nilai jual.

Kata Kunci: Pelatihan, Makanan Herbal, Sumber Daya Manusia

\section{PENDAHULUAN}

Desa Brumbun merupakan desa yang terletak di Kabupaten Madiun, Tepatnya terletak di Kecamatan Wungu. Desa ini memiliki dua wilayah (Dusun) yaitu Sukoreja dan Malang, dimana masing-masing dusun memiliki Dukuh untuk Sukorejo memiliki sepuluh dukuh dan Malang memiliki lima dukuh. Desa Brumbun bisa dibilang masih mempertahan jati diri mereka sebagai Desa pada umumnya dan belum terpengaruh oleh budaya Kota, dikatakan seperti itu karena Desa ini berada di ujung timur dekat dengan tepi lereng pegunungan kota Madiun. Pada awalnya Desa ini tidak memiliki keunggulan apapun, padahal secara geografis dan iklim desa ini memiliki SDA yang sangat melimpah. Banyak tanaman yang di tanam di tempat tersebut dapat tumbuh subur dan sangat baik. disisi lain desa ini dihampit dua aliran sungai yang berasal dari pegunungan, sehingga pertanian didesa tersebut sangat baik. Karena memiliki keunggulan dalam hal sistem irigasi.

Selain memiliki SDA yang melimpah Desa Brumbun juga memiliki SDM yang potensial. Ini dibuktikan dengan para pemuda karang taruna yang memanfaatkan dua aliran sungai yang berasal dari pegunungan dengan membuat tempat wisata pada tahun 2017 yang dinamakan dengan wisata tubing, yang dimana pada awalnya sungai tersebut hanya dibuat untuk mandi dan mencuci oleh masyarakat desa tersebut. Dari hal tersebut mulai membuka citra dan nama baik dari desa tersebut, keunggulan-keunggulan dari desa tersebut pun juga mulai terlihat. Hingga pada akhirnya Desa Brumbun dikenal dengan Desa wisata oleh orang-orang. Tahun 2019 Desa Brumbun mulai menambah wahana yang ada seperti body 
rafting, arum jeram, dan area outbond. Selain itu pemuda karang taruna juga membuat sebuah cooking class yang dikhususkan untuk para pengunjung yang ingin belajar memasak dengan menu yang dimasak adalah jemblem.

Berkembangnya wisata alam desa ini tidak luput dari pengaruh para pemuda Karang Taruna desa dan masyarakat desa tersebut yang sangat membantu dalam pembangunan desa. Sehingga menciptkan antusiasme para pengunjung untuk menikmati wisata tersebut. Ini sesuai dengan julukan desa tersebut yaitu Desa Wisata, dimana tujuan desa tersebut mengenalkan citra desa tanpa mengubah ciri khas dari desa itu sendiri. Perlunya perhatian yang sangat penuh dari pemerintah desa dan perhatian secara khususnya, agar dapat mempertahankan pengelolalaan dari wisata alam tersebut. Sehingga tidak hilang ciri khas dari desa itu sendiri. Tidak hanya itu perlunya pengembangan SDA agar dapat menciptakan desa yang kaya akan aset potensial menjadi desa yang sejahtera sehingga banyaknya aset alam dapat terolah dengan baik oleh SDM yang mumpuni. Menurut Hermen Malik (2019) "orientasi pembangunan SDM masyarakat desa adalah dalam rangka mengolah dan mendayagunakan potensi-potensi daerah, baik yang bersifat natural dan kultural.
Dengan pembangunan SDM masyarakat desa diharapkan potensi-potensi di desa benar-benar bisa diolah secara maksimal oleh masyarakat desa untuk meningkatkan kemakmuran dan kesejahteraan masyarakat desa itu sendiri" (Hermen Malik, 2019:108). Jadi pendayagunaan dan pengolahan potensipotensi dilakukan dengan inisiatif masyarakat itu sendiri, dilakukan oleh masyarakat dan memberi kemanfaatan untuk masyarakat.

Berdasarkan survey, peneliti menyoroti beberapa SDA yang tidak terlalu diperhatikan. Ketika tilik desa beberapa tumbuhan herbal tidak dimanfaatkan dengan baik atau malah bahkan terabaikan misalnya seperti Daun Katu, Daun Kelor, Daun Pepaya dan Lempoyang. Karena disana mayoritas pekerjaan masyarakat petani maka tumbuhan-tumbuhan tersebut tidak terlalu menjadi perhatian penting. Yang lebih dipentingkan untuk diolah menurut masyarakat yaitu yang bagi mereka mudah di temui sesuai dengan wawancara dengan Bapak Sugeng Pranggono selaku Kepala Desa Brumbun "disini itu sebenarnya banyak tumbuhan-tumbuhan yang kurang termanfaatkan, karena mayoritas masyarakat sini sendiri yaitu bekerja sebagai petani. Jadi fokus masyarakat yaitu mengolah bahan yang 
menurut mereka mudah di dapatkan seperti ketela, jagung, dan padi”. Padahal jika jelajahi pada Desa Brumbun memiliki aset yang banyak, memang benar mayoritas masyarakatnya petani karena dialiri dua sumber air sehingga memudahkan sistem irigasinya. Namun, disamping itu banyak tumbuhantumbuhan yang hidup dan tidak diperhatikan padahal itu dapat menjadi aset desa.

Masalah lain yang muncul pada saat survey yaitu walaupun Desa Brumbun memiliki SDM yang potensial, Akan tetapi SDM itu sendiri belum menyadari keunggulan yang mereka miliki. Ketika wawancara dengan Ketua Karang Taruna Mas Adip "sebenarnya SDM desa ini banyak dan memiliki potensial akan tetapi mereka belum paham keunggulan yang mereka miliki, perlunya pengembangan SDM kami secara baik sehingga mereka paham keunggulan yang mereka miliki dapat menambah pemasukan dari desa ini. pemudanya pun cukup banyak tapi pemuda sekaran seperti sudah melupakan tanggung jawab mereka terhadap desanya sendiri mereka lebih mementingkan media sosial yang tidak nyata daripada membangun desa mereka. Bagaimanapun metodenya tolong kembangkan SDM kami”. Dalam wawancara tersebut menjelaskan bahwasanya SDM Desa
Brumbun sudah potensial hanya perlu pengembangan secara lanjut agar dapat menambah pemasukan desa serta dapat memanfaatkan SDA yang ada. Maka dari permasalahan diatas peneliti tertarik untuk mengadakan pengabdian dengan judul "Sosialisasi dan Pelatihan Pembuatan Makanan Herbal Sebagai Upaya Pengembangan SDM Desa”.

Beberapa penelitian yang sudah menggunakan konsep sosialisasi dan pelatihan sebagai upaya pengembangan SDM desa yaitu antara lain yang dilakukan oleh I Nyoman Meirejeki dengan judulnya "Pengembangan Desa Wisata Melalui Peningkatan Kualitas SDM Dan Pemanfaatan Bahan Baku Lokal Di Desa Wisata Belimbing, Tabanan", pelatihan mendapat respon baik dan sangat luar biasa dari pegiat pariwisata, pokdarwis serta ibu PKK. Berangkat dari potensi yang dimiliki desa, Pelatihan tersebut memiliki manfaat berupa: 1) dapat memperkaya kemampuan intelektual demi meningkatkan kompetensi saat memasuki dunia kerja terutama menyikapi perkembangan desa wisata, 2) dapat mengembangkan produk wisata kreatif yang ditawarkan kedepannya dengan memanfaatkan bahan lokal dan potensi desa, 3) membantu para pengelola jalur tracking untuk 
mengembangkan jalur tracking lebih kreatif. (I Nyoman Dkk, 2018:31)

Penelitian selanjutnya oleh Wulan Suryandani dengan judul "Pengembangan Kualitas SDM Dan Usaha Kelompok Pengrajin Tempe Desa Tahunan Kecamatan Sale Kabupaten Rembang" mengemukakan bahwasanya pelatihan efektif dalam meningkatkan kualitas SDM dan juga manajemen usaha, meskipun seperti itu pendampingan yang dilakukan akan akan menjaga keberlangsungan program. Hasil yang didapat dari penelitian ini dari pelatihan dan pendampingan kelompok pengrajin tempe mampu membuat catatan keuangan secara sederhana secara baik dan melakukan promosi ke media sosial. (Wulan Suryandani dan Aviv Mahmudi, 2018:337)

Penelitian ini diawali dari aset potensi yang dimiliki di suatu desa, bukan dari masalah yang harus dipecahkan. Pada penelitian ini lebih memberikan nilai positif pada objek yang akan dikembangkan bukan pemecahan. Dengan metode ABCD (Asset Based Community Development). Harapannya aset yang berasal dari potensi SDA dapat dikembangkan oleh SDM itu sendiri sehingga dapat menambah income desa maupun akan menjadi ciri khas keunggulan dari SDM desa itu.
METODE DAN PELAKSANAAN

Asset Based

Community

Development

Penelitian ini menggunakan pendekatan (ABCD), menurut Munawar Ahmad (2007) "(ABCD) Asset Based Community Development merupakan sebuah model atau metode pengembangan masyarakat yang mengutamakan pemanfaatan aset dan potensi disekitar wilayah yang ditempati masyarakat" (Munawar Ahmad, 2007:113). Pelatihan yang dilakukan ini berdasarkan penemuan asset dan potensi yang sudah ada di Desa tersebut kemudian dikembangkan lebih lanjut melalui pelatihan dan pendampingan untuk menjadikan aset dan potensi di sekitar masyarakat dapat dimanfaatkan dengan baik.

Secara konsep aset dibagi menjadi dua yaitu: nyata (tangible) dan tidak nyata (intangibel), adapun pembagian dari penjelasan tersebut. Aset nyata (tangible asset) meliputi mesin, barang yang memiliki kekuatan baik sifat maupun ketahanan yang lama, hasil alam, dan hak cipta. Kemudian asset tidak nyata (intangibel asset) yang meliputi 1.) Manusia (human capital) yaitu secara nyata manusia ada akan tetapi dikatakan tidak nyata mereka memiliki kemampuan, pengetahuan, pengalaman, keterampilan, 
dan visi misi. 2.) Budaya (culture) yaitu subjek yang dimiliki oleh budaya seperti cara berpakaian, kebiasaan, kemampuan komunikasi, dan kharakteristik. 3.) Modal sosial informal (informal social capital) yaitu modal organisasi atau struktur organisasi yang ada di daerah ataupun desa tersebut. 4.) bentuk partisipasi dalam politisi. (Amandus Jong Tallo Dkk, 2020:79)

pelatihan ini ditujukan kepada sebuah komunitas masyarakat, komunitas tersebut lebih jelasnya yaitu perkumpulan Ibu-ibu PKK. Ibu-ibu PKK yang terdapat di Desa Brumbun merupakan komunitas ibu-ibu yang terdiri dari empat pokja (kelompok kerja), yang mana setiap pokja mempunyai bidangnya masing-masing. Perkumpulan Ibu-ibu PKK ini menjadi aset penting bagi Desa Brumbun, komunitas ini sudah mengikuti berbagai lomba dan sangat kompeten dalam bekerja. Maka dari itu pelatihan ini di fokuskan pada perkumpulan Ibu-ibu PKK Desa.

Pelatihan ini bertujuan untuk memberi pemahaman tentang pembuat makanan herbal yang berasal dari daun kelor dan katu. Pelatiahan dilakukan sesuai potensi yang dimiliki desa, Desa Brumbun sendiri memiliki SDA yang banyak dan melimpah. Berdasarkan survey asset ada beberap tanaman yang belum dimanfaatkan dengan baik oleh masyarakat desa misalnya daun kelor dan katu, ini dapat dibuktikan yaitu pengetahuan tentang mengolah daun kelor dan katu. Beberapa masyarakat hanya menjawab dijadikan sayur dan untuk memulasari jenazah, padahal lebih dari itu daun-daun tersebut dapat dimanfaat sengan berbagai olahan. Manfaatnya sendiri banyak seperti obat asam urat, mengurangi gula darah, menjaga imun tubuh, penglancar ASI untuk ibu hamil dan masih banyak lagi. Maka dapat disimpulkan alasan pelatihan ini dilakukan yaitu berdasarkan aset yang ada pertama adanya SDM yang potensial (perkumpulan Ibu-ibu PKK yang dirasa pasti memiliki kemampuan memasak yang baik). kedua, SDA yang melimpah (tumbuh berbagai tanaman yang dapat dimanfaatkan). Ketiga sikap menerima, terbuka, dan antusias dari masyarakat untuk diberi pelatihan.

Mobilisasi (pergerakan sosial) dalam metode $\mathrm{ABCD}$ yang digunakan dalam program ini yaitu: (Ahmadi dkk, (2021:47)

\section{Appreciative Inquiry (Penemuan Apresiatif)}

AI merupakan sebuah model pendampingan dengan menemukan, mencari, dan menyelidiki secara sistematis potensi masa lalu dan masa 
kini di dunia sekitar sehingga dapat meningkatkan nilai. Proses AI sendiri memiliki 4 tahap yaitu dikenal 4-D meliputi discovery, dream, design, destiny. yang di realisasikan denga wawancara dengan tokoh masyarakat dan melakukan diskusi beberapa pihak.

Community Mapping (Pemetaan Komunitas)

Community mapping merupakan visualisasi dari pengetahuan masyarakat untuk bertukar informasi dan kesempatan bagi seluruh anggota masyarakat untuk berpartisipasi dalam kegiatan guna mempengaruhi lingkungan dan kehidupan mereka. Proses pemetaan ini melibatkan beberapa anggota masyarakat seperti institusi sipil lokal, sekumpulan warga, dan komunitas organisasi masyarakat. Tujuan dari community mapping yaitu untuk mengidentifikasi kekuatan yang mereka miliki dan apa yang bisa dilakukan dari kekuatan baik itu keterampilan dan kemampuan mereka miliki. Sehingga mereka ingin diundang dan dipilih untuk berbagi kekuatan mereka untuk kebaikan seluruh kelompok.

\section{Transect (Penelusuran Wilayah)}

Transect (penelusuran wilayah digunakan untuk menemukan asset yang mereka miliki, baik itu aset fisik maupun aset non fisik secara terperinci. Transect merupakan garis penelusuran sepanjang area tertentu sebagai usaha menemukan keragaman sebanyak mungkin dengan disertai dokumentasi, penilaian aset dan peluang. Diwujudkan dalam penilitian ini yaitu tilik desa dan survey desa untuk menemukan fakta seperti tanaman, sungai, tipe tanah, dan jenis tanah.

\section{Pemetaan Aset Asosiasi dan Institusi}

Merupakan proses interaksi yang mendasarkan pada terbentuknya lembaga sosial dan institusi yang biasannya terdapat pada desa seperi karang taruna, perkumpulan Ibu PKK, dan kelompok tani. Dengan melihat pemetaan asosiasi maupun institusi dari masyarakt, maka dapat setelah itu dapat di identifikasi kekuatan dari mereka.

\section{Individual Inventory Skill (Pemetaan Aset Individu)}

Alat yang digunakan dalam pemetaan ini yaitu berbentuk form yang diisi dengan dengan interview dan wawancara guna sebagai tolak ukur untuk memberdayakan

masyarakat, membangun hubungan baik dengan masyarakat, mengidentifikasi aset personal dari masyarakat.

\section{Leaky Bucket (Sirkulasi Keuangan)}

Teknik pendampingan mengetahui

Siklus ekonomi yang terdapat pada masyarakat seperti kas, barang dan jasa 
dalam kehidupan masyarakat sehari-hari guna mengetahui sebarapa jauh tingkat pengembangan ekonomi lokal mereka yang dilihat dari kekuatan ekonomi yang masuk dan keluar. Maka ABCD dalam leaky bucket digunakan sebagai alat analisa yang cermat untuk mengetahui masuk dan keluarnya ekonomi lokal dari suatu komunitas masyarakat.

\section{Low Hanging Fruit (Skala Prioritas)}

Setelah masyarakat mengetahui potensi, kekuatan dan peluang yang mereka miliki melalui informasi dengan pemetaan aset, penulusuran wilayah, pemetaan aset individu, pemetaan secara formal/institusi, dan mempunyai mimpi. Kemudian bagaimana merealisasikan dari semua itu mengingat terbatasnya ruang gerak dan waktu untuk mewujudkan semuannya. Maka adanya skala prioritas ini digunakan untuk merealisasikan salah satu mimpi denga fokus potensi yang dimiliki yang di tuangkan dalam tahap design (perencanaan program kerja).

Berangkat dari asset dan potensi yang ada, peneliti akhirnya menentukan dan memutuskan untuk membuat sebuah pelatihan dan sosialisasi pembuatan makan herbal guna mengembangkan SDM desa Brumbun. Tujuan dari pelatihan dan sosialisasi ini yaitu mengembangkan potensi agar lebih muncul dan menjadi ciri khas dari desa agar dapat menjadi pemasukan desa, satu sisi lain masyarakat menjadi paham akan kemampuan yang dmilikinya. Adapun tahapan yang dilakukan dalam program ini:

\section{Inkulturasi}

Tahap pertama pada metode (ABCD) yaitu inkulturasi, inkulturasi adalah tahapan dimana peneliti membangun kepercayaan masyarakat terhadap apa yang dilakukan peneliti untuk kedepannya. Tujuan dari tahap ini adalah memberi pemahaman terhadap komunitas masyarakat untuk percaya kepada peneliti atau mahasiswa, apa yang dilakukan baik program kerja ataupun kegiatan yang dilakukan tidak lain untuk menggali potensi yang ada di desa dengan memanfaatkan SDM yang ada. Artinya kegiatan dilakukan nantinya akan memberi pengertian kepada masyarakat bahwa peneliti hanya memberi stimulus dari kegiatan yang dilakukan akan tetapi untuk selebihnya masyarakat itu sendiri yang mengembangkan potensi mereka sendiri kedepannya. Karena sifat dari pengabdian ini hanya sementara.

Pada tahap ini kegiatan yang telah dilakukan antara lain bersosialiasasi langsung terhadap masayarakat dengan melakukan tilik desa dan bersilahturahmi dengan ketua RT setempat dengan 
harapan dapat terjalin rasa saling percaya antara mahasiswa KPM dan masyarakat sekitar melalui perwakilan ketua RT. Sehingga hasil dari kegitan tersebut dapat menunjukka aset dari desa itu dan kharakteristik masyarakat dari desa tersebut. Tahap inkulturasi ini juga dapat digunakan untuk mengetahui sistem kerja masyarakat, apakah masyarakat masih menggunakan cara-cara kuno (tradisional) atau sudah modern, Apakah masyarakat masih menerapkan sistem gotong royong atau malah bekerja secara mandiri. Karena nantinya seluruh sistem kerja itu secara langsung maupun tidak langsung akan berpengaruh terhadap kegiatan program kerja yang direncakan (Arial Agung Prasetiyawan, 2020:107).

\section{Discovery}

Tahap discovery yaitu pada tahap ini kebanyakan dalam metode (ABCD) peneliti menemukan aset dengan beberapa cara untuk mengungkap potensi yang dimiliki dari Desa Brumbun ini. pada tahap ini kegiatan yang dilakukan yaitu melakukan wawancara dan diskusi ringan dengan tokoh masyarakat, kepala desa, sekertaris desa, ketua karang taruna dan ketua ibu PKK. Biasanya yang didiskusikan yaitu mengenai aset apa yang dimiliki, kebiasaan masyarakat dan sifat dari masyarakat apakah terbuka atau tertutup.
Dalam tahap ini peneliti atau mahasiswa mengungkap potensi ataupun aset yang dimiliki desa dengan menemui pemerintah desa terlebih dahulu terutama kepala desa dan sekretaris desa. Kemudian melakukan diskusi dengan pemerintah desa. Dimana nantinya diskusi itu untuk menentukan program kerja paneliti. Setelah menemui pemerintah desa untuk selebihnya melakukan wawancara dengan komunitas masyarakat seperti tokoh masyarakat dan ketua karang taruna, ini dilakukan yaitu untuk memantapkan program kerja yang akan disusun agar terstruk dan terarah sehingga mecapai tujuan yang direncanakan. Namun untuk memastikan ada sinkronisasi atau keterkaitan antara wawancara yang dilakukan dan fakta yang ada, maka setelah wawancara yang berkaitan dengan aset dengan beberapa tokoh. Untuk selanjutnya melakukan keliling desa dengan tujuan menyinkronkan antara data wawancara dan kenyataan yang ada. Ini dimaksudkan agar nanti saat program kerja dilakukan tidak ada kesenjangan yang menjadikan program kerja terhenti dan harus membuat program kerja baru.

\section{Design}

Pada tahap ini dalam metode (ABCD) yang dilakukan yaitu memetakkan aset, dengan tujuan aset di 
petakkan agar memudahkan peneliti dalam membuat sebuah program kerja. Dalam penelitian ini hasil dari wawancara dan keliling desa terciptalah program kerja yaitu sosialisasi dan pelatihan makanan herbal. Ini sesuai aset desa yang di temukan yaitu daun kelor dan katu, sesuai pertimbangan keadaan yang mana ini dimasa pandemi maka perlunya mengkonsumsi makanan yang dapat menambah imun. Banyaknya manfaat dari tumbuhan tersebut Mulai dari menambah imun, obat kolesterol, dan dapat menurunkan gula serta berserat tinggi. Nantinya ketika aset sudah dirasa cocok maka dapat digunakan dalam program kerja, selanjutnya yaitu merencanakan waktu program kerja dan tempat pelaksanaan. Untuk pembuatan program kerja ini sebenarnya dibuat dengan bantuan pemerintah desa, bantuan yang diberikan lebih kepada waktu pelaksanaan program dan tempat untuk judul kegiatan, dan model pelatihan yang dilakukan program itu berasal dari mahasiswa sendiri, karena di era PPKM darurat ini kegiatan harus sesuai dengan aturan pemerintah desa. Maka agar program kerja berjalan dengan baik dan sesuai aturan serta tidak terkendala karena melanggar aturan, pihak pemerintah desa juga membantu pembuatan program kerja terutama dalam hal waktu dan jumlah responden yang dijadikan sasaran. dengan melakukan konsultasi dengan Kepala Dusun Sukorejo yang kemudian dialihkan pada ibu PKK.

Kemudian keputusan sosialisasi dan pelatiham pembuatan makanan herbal pada akhirnya sesuai diskusi yaitu hari ditentukan oleh kesiapan anggota ibu-ibu PKK dengan jumlah 8 orang dimana berdasarkan peraturan pemerintah desa yang tidak membolehkan mengundang orang dengan jumlah banyak karena situasi pandemi, maka yang diprioritaskan yaitu ibu PKK yang memiliki usaha dengan maksud agar mempermudah menjalankan usaha nantinya jika ada tindak lanjut.

\section{Define}

Pada tahap ini define dalam metode ABCD digunakan untuk menganalisis pelaksaan program kerja, yang mana program kerja akan terlaksana apabila mendapat dukungan dari masyarakat. Pada saat kegiatan dilakukan ibu-ibu PKK sangat antusias dan memberikan respon positif dari diadakannya pelatihan, ini dapat dibuktikan dengan semangatnya ibu-ibu dalam mengikuti kegiatan. Bahkan inisiatif ketu ibu-ibu PKK untuk memfasilitasi dalam hal peralatan menandakan bahwa kegiatan ini sangat 
didukung penuh. Dan hasilnya pelatihan dapat berjalan hingga selesai tanpa kendala. Disatu sisi lain pelatihan juga sangat didukung oleh pemerintah desa, pemerintah desa ingin setelah pelatihan selesai ada output yang dihasilkan dari kegiatan.

Dalam praktiknya mahasiswa memberi fasilitas yaitu bahan-bahan untuk membuat makanan dan membuatkan label usaha, dimana label yang dibuat belum ada surat izin. Ketika surat izin sudah jadi nantinya label akan dibuat lagi yang baru dengan menyertakakn izin usaha. Disini pembuatan makanan herbal didukung penuh oleh Pemerintah Desa dengan pernyataan pak Sekertaris desa Brumbun "apabila usaha jalan maka kami dari pihak desa akan membuatkan surat MOU atau surat izin usaha". Artinya jika kegiatan pembuatan makanan herbal jalan bukan hanya sebagai pelatihan saja, namun menjadi sebuah usaha yang secara nyata jalan. Maka pihak desa akan memberikan surat MOU. Berdasarkan hal tersebut para peneliti atau mahasiswa menyarankan agar ibu PKK yang mengikuti pelatihan membentuk sebuah kelompok usaha yang dibantu mahasiswa, dimana mahasiswa akan siap memberikan bantuan baik pembuatan label dll. Ini dimaksudkan agar setelah KPM selesai ibu PKK mempunyai sebuah usaha yang dapat menjadi income desa. Kemudian sosialisasi dan pelatihan mendapat respon positif dari ibu PKK, ibu PKK sangat antusia dan semangat dengan kegiatan yang dilakukan.

\section{Refleksi}

Pada tahap ini refleksi digunakan untuk melihat sejauh mana metode (ABCD) berdampak pada perubahan seiring berjalannya kegiatan yang dilakukanArtinya tahap refleksi digunakan untuk melihat sejauh mana hasil kegiatan berjalan, apakah ada perkembangan dari masyarakat yang mengikuti kegiatan atau hanya terkesan diam ditempat dan tidak ada perubahan apapun. Ditahap refleksi ini Seiring berjalannya waktu, kegiatan secara tidak langsung memberi dampak signifikan yang membuat masyarakat untuk berwirausaha, namun perlunya pendampingan lebih terkait berjalannya program kegiatan makanan herbal. Pendampingan dilakukan agar program berjalan tidak hanya sebatas pelatihan akan tetapi menjadi sebuah usaha yang dapat berkembang.

Berdasarkan antusiasme ibu PKK peneliti dapat menarik kesimpulan usaha semestinya sudah terbentuk, namun ketika dilakukan penelaahan kembali dan pertemuan dengan ketua ibu PKK 
ternyata akibat adanya pandemi belum dapat beroprasi penuh karena pembatasan ruang gerak, disatu sisi lain kebanyakan kelompok ibu PKK yang mengikuti pelatihan juga memiliki usaha mandiri yang harus dijalankan. akan tetapi nantinya usaha akan coba untuk beroprasi dan tetap melanjutkan hasil dari kegiatan yang dilakukan setelah PPKM darurat selesai. Untuk melihat apakah ada perkembangan dari adannya pelatihan, kami selalu melakukan diskusi ringan kepada ketua ibu-ibu PKK terkait hal-hal itu. Ketua ibu-ibu PKK Bu Wondo mengatakan "ini masih belum berjalan karena situasi pandemi dan apalagi di situasi PPKM darurat, masih belum bisa mengadakan kumpul-kumpul. Makanya belum ada pembahasan lagi, rencanannya nanti pada bulan agustus". Artinya belum berjalan saat ini karena situasi pandemi karena belum bisa berkumpul untuk membahas tindak lanjut dari pelatihan kemarin, kemungkinan besar nanti pada bulan agustus akan dibahas dan mulai dijalankanBagian ini berisi metode pengabdian dan pelaksanaan kegiatan.

\section{Pelaksanaan Kegiatan}

Kegiatan dilakukan di Desa Brumbun, Kecamatan Wungu, Kabupaten Madiun. Dilaksanakan pada tanggal 5 juli 2021 sampai dengan 13 agustus 2021 dengan jumlah peserta empat mahasiswa yang semuanya terdiri dari mahasiswa aktif semester 7 , jurusan ekonomi syariah.

\section{HASIL DAN PEMBAHASAN}

\section{A. Langkah Awal}

Pada awalanya sebelum terjun kepelatihan, peneliti melakukan beberapa survey dengan tujuan hasil dari survey tersebut nantinya dibuat sebuah proker yang dirasa sesuai dengan kondisi masyarakat serta berpotensi dapat mengembangkan masyarakat Desa Brumbun. Survey dimulai pada hari sabtu tanggal 26 juni 2021, pada tanggal tersebut tujuan dari peneliti yaitu mencari izin kepada kepala desa untuk melakukan KPM di desa Brumbun dan bertanya mengenai asset yang ada di desa tersebut. Mendapatkan hasil KPM diterima beserta penjelasan aset, namun itu hanya sebatas izin verbal atau secara lisan. Secara izin resmi harus melakukan izin ulang dengan petugas pemereintah desa yang lain. berbekal izin dari kepala desa dan penjelasan aset yang diberikan, tanggal 27 juni 2021 peneliti melakukan survey desa guna melihat fakta secara real apa kelebihan dan kekurangan dari desa tersebut. Dan fakta yang ada Desa Brumbun merupakan desa yang subur dengan kualitas tanah yang baik dan air yang melimpah, sistem irigasinya pun terkenal baik serta banyak tumbuhan 
yang tumbuh didesa ini. untuk memantapkan melakukan KPM di desa tersebut tanggal 1 july 2021 pemerintah desa mengizinkan untuk diadakan KPM di desa tersebut dengan bukti dibuatkan surat rekomendasi sebagai bukti fisik dibolehkan adanya KPM.

Setelah adanya surat rekomendasi, maka setelah itu perencanaan program yang dibantu oleh pihak desa. maksud dari pembuatan proker yang dibantu oleh pihak pemerintah desa ini yaitu untuk membuat sebuah jadwal agar tersusun dengan rapi dan berjalan lanacar juga tidak terkendala dan bertabrakan dengan acara desa nantinya. Berikut gambaran jadwal rencana program kerja yang disusun:

Tabel 1.1

JADWAL RENCANA PROGRAM KERJA KPM-DDR 2021

Desa Brumbun, Kecamatan Wungu,

Kabupaten Madiun

\begin{tabular}{|l|l|l|c|l|}
\hline No & $\begin{array}{l}\text { Nama } \\
\text { Kegiat } \\
\text { an }\end{array}$ & $\begin{array}{l}\text { Sasaran/J } \\
\text { umlah }\end{array}$ & Output & $\begin{array}{l}\text { Jadwa } \\
\text { l }\end{array}$ \\
\hline 1. & Pemb & Perangkat & - & 5 juli \\
& ukaan & $\begin{array}{l}\text { desa yang } \\
\text { bersangku }\end{array}$ & & 2021. \\
& dan & & Pukul \\
& tilik & tan & & o8.oo \\
& desa & & & \\
\hline 2. & Pelati & Ibu-ibu & Stik & 6 juli \\
\hline
\end{tabular}

\begin{tabular}{|c|c|c|c|c|}
\hline & $\begin{array}{l}\text { han } \\
\text { dan } \\
\text { sosiali } \\
\text { sasi } \\
\text { pemb } \\
\text { utan } \\
\text { maka } \\
\text { nan } \\
\text { herbal } \\
\text { besert } \\
\text { a } \\
\text { pemas } \\
\text { aran }\end{array}$ & $\begin{array}{l}\text { perwakila } \\
\text { n RT.1-6 }\end{array}$ & $\begin{array}{l}\text { dan } \\
\text { cara } \\
\text { pemasa } \\
\text { ran }\end{array}$ & $\begin{array}{l}2021 . \\
\text { Pukul } \\
\text { o8.0o }\end{array}$ \\
\hline 3. & $\begin{array}{l}\text { Pemb } \\
\text { agian } \\
\text { maske } \\
\mathrm{r} \\
\text { gratis }\end{array}$ & $\begin{array}{l}\text { Masyarak } \\
\text { at desa }\end{array}$ & Masker & $\begin{array}{l}\text { juli } \\
2021\end{array}$ \\
\hline 4. & $\begin{array}{l}\text { Pelati } \\
\text { han } \\
\text { dan } \\
\text { sosiali } \\
\text { sasi } \\
\text { mena } \\
\text { nam } \\
\text { sayur } \\
\text { secara } \\
\text { minim } \\
\text { alis }\end{array}$ & $\begin{array}{l}\text { Ibu-ibu } \\
\text { perwakila } \\
\text { n RT.7-15 }\end{array}$ & $\begin{array}{l}\text { Pengeta } \\
\text { huan } \\
\text { menana } \\
\text { m sayur } \\
\text { secara } \\
\text { minima } \\
\text { lis }\end{array}$ & $\begin{array}{l}12 \text { juli } \\
2021 . \\
\text { Pukul } \\
08.00\end{array}$ \\
\hline 5. & $\begin{array}{r}\text { Bag } \\
\text { i-bagi } \\
\text { sayur } \\
\text { gratis }\end{array}$ & $\begin{array}{l}\text { Masyarak } \\
\text { at desa } \\
\text { (yang } \\
\text { dianggap }\end{array}$ & $\begin{array}{l}\text { Sayur } \\
\text { mentah } \\
\text { untuk } \\
\text { dimasa }\end{array}$ & $\begin{array}{l}16 \text { juli } \\
2021\end{array}$ \\
\hline
\end{tabular}




\begin{tabular}{|c|c|c|c|c|}
\hline & & $\begin{array}{l}\text { kurang } \\
\text { mampu) }\end{array}$ & $\mathrm{k}$ & \\
\hline 6. & $\begin{array}{l}\text { Pel } \\
\text { atihan } \\
\text { dan } \\
\text { sosiali } \\
\text { sasi } \\
\text { cara } \\
\text { pemb } \\
\text { uatan } \\
\text { foto\&v } \\
\text { ideo } \\
\text { promo } \\
\text { si }\end{array}$ & $\begin{array}{l}\text { Pegiat } \\
\text { UMKM }\end{array}$ & $\begin{array}{l}\text { Pengeta } \\
\text { huan } \\
\text { cara } \\
\text { promos } \\
\text { i dan } \\
\text { memas } \\
\text { arkan }\end{array}$ & $\begin{array}{l}19 \text { juli } \\
2021 . \\
\text { Pukul } \\
\text { o8.00 }\end{array}$ \\
\hline 7. & $\begin{array}{l}\text { Meng } \\
\text { ajar } \\
\text { anak } \\
\text { TPA }\end{array}$ & $\begin{array}{l}\text { Sekolah } \\
\text { TPA yang } \\
\text { terdapat } \\
\text { di desa } \\
\text { brumbun }\end{array}$ & $\begin{array}{l}\text { pengeta } \\
\text { huan }\end{array}$ & - \\
\hline 8. & & & & 27 juli \\
\hline 9. & $\begin{array}{l}\text { Mengi } \\
\text { kuti } \\
\text { acara } \\
\text { rutin } \\
\text { desa }\end{array}$ & - & - & $\begin{array}{l}\text { Sesuai } \\
\text { jadwal } \\
\text { desa }\end{array}$ \\
\hline 10. & $\begin{array}{l}\text { penut } \\
\text { upan }\end{array}$ & $\begin{array}{l}\text { Perangkat } \\
\text { desa yang } \\
\text { bersangku } \\
\text { tan }\end{array}$ & - & $\begin{array}{l}13 \\
\text { agust } \\
\text { us } \\
2021\end{array}$ \\
\hline
\end{tabular}

Dalam jadwal perencanaan program kerja tersebut, jadwal yang dibuat tidak berjalan sesuai waktu akan tetapi ada perubahan sedikit, karena desa juga mempunyai program kerja yang membutuhkan bantuan mahasiswa. Sehingga jadwal yang dirancang ini hanya sebatas acuan yang akan ada perubahan sewaktu-waktu tergantung kegiatan jadwal desa yang membutuhkan bantuan mahasiswa. Ini dimaksudkan agar mahasiswa tidak hanya terikat dengan proker mahasiswa sendiri kan tetapi dapat mengabdi kepada desa sesuai dengan dasar KPM itu sendiri.

Inti dari laporan ini yaitu membahas hasil dari proker yang dijalankan oleh peneliti, sesuai tema maka yang menjadi tolak ukur keberhasilan yaitu kegiatan pelatihan pembuatan makanan stik herbal dilaksanakan pada tanggal 7 juni 2021. Dilaksanakan tanggal tersebut karena ini berdasarkan arahan dari kasun Dusun Sukorejo yang kemudian diarahkan ke ketua Ibu PKK, ketua Ibu PKK menyarankan tanggal 7 karena sekalian mempersiapkan anggota sehingga nanti acara berjalan dengan baik dan tidak ada kendala.

\section{B. Analisis Hasil}

Hasil pelatihan ini di tujukan untuk memberdayakan masyarakat Desa Brumbun dengan memberikan pelatihan kepada yang berpengalaman sehingga hasil dari pelatihan nanti dapat diinformasikan kepada masyarakat lain agar dimengerti oleh masyarakat luas. 
menurut Ardito Bhinardi (2017) mengemukakan "pada hakikatnya pemberdayaan merupakan penciptaan suasana atau iklim yang memungkinkan potensi masyarakat berkembang (enabling) (Ardito Bhinardi, 2017:24). Dalam pendapat tersebut dijelaskan bahwasanya pemberdayaan akan menciptakan suatu iklim dimana iklim tersebut dapat mengembangkan potensi masyarakat, sehingga pelatihan harusnya memberikan suasana yang dapat mengembangkan masyarakat desa. berdasarkan pengamatan peneliti pasca diadakan pelatihan, masyarakat sangat antusias ini dibuktikan dengan semangatnya para ibu-ibu PKK dalam mengikuti pelatihan. Ini berpotensial mengeluarkan semangat berwirausaha dari kelompok ibu-ibu PKK tersebut yang mengikuti pelatihan, sehingga pelatihan ini juga mestimulus kelompok ibu-ibu PKK untuk mengembangkan hasil pelatihan mejadi suatu aset desa yang mendatangkan income, disatu sisi lain tumbuhan yang dianggap tidak termanfaat menjadi dapat dimanfaatkan dengan baik dimana tumbuhan daun kelor dan katu merupakan aset yang ada didesa yang perlu dimanfaatkan sehingga dapat mengembangkan potensi alam desa.
Sumber daya sendiri merupakan tolak ukur yang penting untuk melihat berkembang atau tidaknya suatu, artinya desa yang bisa memanfaatkan sumber dayannya dengan baik dapat dikatakan bahwa desa tersebut sudah berkembang. Baiquni (2006) dalam buku Ardito Bhinardi mengemukakan untuk mewujudkan kesejahteraan penduduk pedesaan dapat dilakukan dengan memanfaatkan sumberdaya yang menyangkut tiga pilar yaitu: 1) pengelolaan sumberdaya pedesaan yang berkelanjutan dalam mendukung kehidupan penduduk dipedesaan; 2) pemanfaatan sumberdaya pedesaan untuk memperkuat sosial ekonomi penduduk melalui pemberdayaan masyarakat desa dan institusi terkait; 3) pemahaman tentang permasalahan dan potensi sumberdaya pedesaan. Dalam pelatihan ini jika mengaitkan dengan pendapat tersebut pelatihan memang digunakan untuk mengembangkan SDM desa dan memanfaatkan SDA desa yang tidak termanfaatkan secara penuh. Pelatihan berguna untuk mengelola desa dengan persepsi jangka panjang. Pertama, pelatihan itu nantinya mendukung masyarakat desa untuk mengelola sumberdayanya yang kemudian dijadikan aset dan dapat mendatangkan income. Income itu nanti dijadikan untuk 
pendapatan desa maupun kelompok kecil yang mengikuti pelatihan. Kedua, jika rencana usaha dari pelatihan itu berjalan, dari pihak pemerintah desa akan mencarikan MOU dan surat izin usaha, dimana usaha tersebut nantinya dapat menjadi penguat ekonomi desa. ketiga, sosialisasi dari mahasiswa terkait pelatihan pemanfaatan tumbuhan daun kelor dan katu akan memberi pemahaman terhadap masyarakat yang sebenarnya Desa Brumbun memiliki potensi secara SDA dan SDM.

Dalam pelatihan ini tujuan adanya pelatihan yaitu tidak lain untuk memanfaatkan potensi Desa Brumbun yang belum berkembang sepenuhhya, mengingat potensi dari desa tersebut sangat banyak. Mengacu pada pendapat Sudarmanto dkk (2020) mennyatakan "pada dasarnya pemanfaatan potensi Sumber Daya Masyarakat harus diartikan sebagai usaha pemanfaatan dan mobilisasi sumberdaya yang sebelumnya belum pernah disentuh, tetapi dapat juga berarti meningkatkan daya manfaat dan mengoptimalisasi sumberdaya yang sebelumnya belum digarap" (Eko Sudarmanto dkk, 2020:89). Pelatihan yang dilakukan mahasiswa merupakan sarana memanfaatkan Sumber Daya Alam yang belum termanfaatkan sepenuhnya menjadi potensi yang dapat dijadikan potensi yang termanfaatkan dengan optimal. Pelatihan ini juga merupakan sarana yang dapat membangun SDM juga, menurut Riant Nugroho (2021) mengemukakan bahwa "pelaksanaan pembangunan Sumber Daya Manusia bisa dilakukan melalui pendidikan, pelatihan, dan keikut sertaan dalam seminar, diskusi dan lain sebagainya"(Riant Nugroho, 2021:14). Artinya pelatihan dapat menjadi faktor pendorong pembangunan SDM desa sehingga apabila SDM dapat berkembang maka akan memuncul kreatifitas dan inovatif dari para masyarakat desa.

Adapun keberhasilan dari kegitan yang telah dilakukan dapat dilihat dari beberapa nilai antara lain:

\section{Antusiasme dari responden}

\section{dalam mengikuti pelatihan}

Antusiasme ini dilihat dari semangatnya ibu-ibu PKKyang mengikuti pelatihan dan respon positif yang diberikan kepada mahasiswa. Ibu-ibu PKK mengikuti pelatihan dengan rasa penasaran tinggi, sebagai buktinya ibuibu PKK tidak hanya tinggal diam dan hanya melihat saja. Namun rasa penasaran mereka muncul menjadikan ibu-ibu PKK ingin berlatih membuatnya juga. Ibu-ibu PKK tidak hanya stuck dan diam dalam pelatihan akan tetapi mereka juga memberikan feedback kepada 
mahasiswa dengan memberikan pertanyaan apabila merasa kesulitan. Bahkan ibu-ibu membuat dua kelompok lagi untuk mengukur kemampuan mereka dengan hasil nanti dibandingkan mana yang lebih baik.

Kemampuan responden dalam memahami pelatihan

Setelah dilakukan pelatihan untuk selanjutnya diadakan evaluasi dan tanya jawab terkait pelatihan yang telah dilakukan. Secara pemahaman ibu-ibu PKK sangat baik dalam memahami pelatihan, ini dibuktikan ketika mahasiswa menjelaskan tujuan dari mahasiswa beberapa ibu langsung menambahi pernyataan mahasiswa bahwasannya hasil dari pelatihan ini nanti akan dicoba ibu-ibu dirumah agar hasil bisa maksimal. Karena pelatihan ini memiliki waktu yang singkat dan bisa dibilang belum sepenuhnya maksimal. Akan tetapi secara tata cara sudah memahamkan ibu-ibu PKK.

\section{Tercapainya tujuan dari pelatihan}

Tujuan dari pelatihan itu sendiri yaitu untuk mengembangkan SDM desa dengan memanfaatkan SDA yang ada. Hasil pelatihan itu direncanakan akan dibuat usaha bersama mengatas namakan kelompok ibu-ibu PKK yang mengikuti pelatihan dengan maksud hasil dari usaha nanti digunakan untuk income desa. disisi lain pelatihan sebagai stimulus agar masyarakat berkembang lewat perwakilan ibu-ibu PKK. Karena disituasi pandemi semua ruanga gerak dan kegiatan apapun itu bentuknya sangat diminimalisir, sehingga hanya dapat mengundang sedikit masyarakat sebagai perwakilan dengan maksud mengembangkan SDM desa.

Faktor Pendukung dan Penghambat Pelaksanaan Kegiatan Pelatihan Dan Sosialisasi

\section{Faktor pedukung}

1. Dorongan dan dukungan penuh dari pihak pemerintah desa untuk pengadaan latihan dan sosialisasi dan bekerlanjutan

2. Terdapatnya aset yang sudah diidentifikasi

3. Ketersediaan komunitas Ibu-ibu PKK untuk diikutkan dalam pelatihan

4. Permohonan dari ketua karang tarunan Desa Brumbun untuk membantu mamajukan SDM Desa

5. Antusiasme dari para Ibu-Ibu untuk diadakannya pelatihan pembuatan makanan herbal ini

\section{Faktor penghambat}

1. Terkendala adanya PPKM darurat sehingga harus mengundang 
masyarakat dengan jumlah yang sangat terbatas

2. Waktu pelaksanaan yang tidak sesuai rencana yaitu diadakan pada tanggal 6 juli yang diundur 7 juli yang berdasarkan kesiapan anggota Ibu-ibu PKK.

3. Belum terlaksanannya rencana usaha karena situasi pandemi, Sehingga tidak adanya waktu perkumpulan rutin Ibu-ibu PKK untuk membahas tindak lanjut dari pelatihan.

\section{Hasil Evaluasi}

Berdasarkan dari wawancara peneliti dengan ketua Ibu PKK untuk tindak lanjut dari pelatihan yaitu rencana usaha belum dapat berjalan sesuai rencana, karena terkendala aturan pemerintah yaitu PPKM darurat, sehingga untuk berjalan semestinya perlu pendampingan yang lebih. Kemudian berdasarkan survey menggunakan google form terkait hasil kegiatan dengan beberapa pertannyaan menunjukkan pelatihan baik dan memuaskan.

Jika dilihat berdasarkan prosentase dengan indikator pertanyaan yang meliputi beberapa indikator, pertama yaitu indikator kepuasan dengan skala sangat puas, puas, tidak puas, dan sangat tidak puas menunjukkan prosentase puas yaitu $83,3 \%$ dan sangat puas $16,7 \%$.
Kedua yaitu indikator produk pelatihan bermanfaat dengan skala sangat setuju, setuju, tidak setuju, sangat tidak setuju yang menunjukkan prosentase setuju $50 \%$ dan prosentase sangat puas 50\%. Ketiga yaitu indikator pelatihan memberikan motivasi berusaha dengan skala sangat setuju, setuju, tidak setuju, sangat tidak setuju yang menunjukkan prosentase setuju 83,3\% dan sangat setuju $16,7 \%$. Keempat yaitu indikator sikap mahasiswa memberi pelatihan dengan skala sangat baik, baik, tidak baik, dan sangat tidak baik yang menunjukka sikap baik $16,7 \%$ dan sangat baik $83,3 \%$. Kelima yaitu indikator perkembangan responden dengan skala sangat setuju, setuju, tidak setuju, sangat tidak setuju yang menunjukkan prosentase setuju 83,3\% dan sangat setuju $16,7 \%$. Keenam yaitu indikator tindak lanjut pelatihan menjadi usaha dengan skala ada, tidak ada, mungkin, dan tidak tahu yang menunjukkan prosentase mungkin $50 \%$, ada $33,3 \%$ dan tidak ada $16,7 \%$. Indikator ini menunjukka bahwa terdapat keraguraguan diantara Ibu-ibu PKK yang mengikuti pelatihan dengan skala mungkin menunjukkan prosentase yang bisa dibilang cukup tinggi diantara skala lainnya. Kemudian yang terakhir indikator pemahaman responden terkait pelatihan yang diberikan dengan skala 
sangat paham. Paham, tidak paham, sangat tidak paham menunjukkan prosentase $100 \%$ seluruh Ibu-ibu PKK paham terkait pelatihan yang diberikan mahasiswa.

Dapat disimpulkan berdasarkan data menggunakan google form bahwasannya Ibu-ibu PKK puas dan paham terkait pelatihan yang diberikan mahasiswa, hanya saja terdapat satu indikator yang dimana Ibu-ibu masih ragu-ragu yaitu tindak lanjut pelatihan dan sosialisasi menjadi usaha yang nyata, sehingga ini sangat perlunya pendampingan lebih untuk menyakinkan Ibu-ibu PKK.

\section{Simpulan}

Berdasarkan uraian dari pembahasan bahwa hasil dapat disimpulkan antara lain: 1.) pelatihan ditujukan untuk memperdayakan masyarakat Desa Brumbun dengan sasaran masyarakat yang berpengalaman sehingga dapat diinformasikan dengan luas, 2.) pelatihan digunakan untuk mengembangkan SDM dan memanfaatkan SDA yang belum termanfaatkan secara penuh, 3.) tujuan dari pelatihan yaitu untuk memanfaatkan potensi Desa Brumbun yang belum termanfaatkan sepenuhnya mengingat potensi dari desa tersebut sangat banyak, 4.) tolak ukur keberhasilan dari kegiatan yaitu antusias responden dalam mengikuti pelatihan, kemampuan responden dalam memahami pelatihan yang diberikan, tercapainya tujuan dari pelatihan, 5.) hasil evaluasi menunjukkan bahwa Ibu-ibu paham dan puas terkait pelatihan yang diberikan, hanya saja masih ada keraguan dalam tindak lanjut menjadi usaha nyata maka masih perlunya pendampingan lebih.

\section{Saran}

Ibu-ibu PKK puas dan paham terkait pelatihan yang diberikan mahasiswa, hanya saja terdapat satu indikator yang dimana Ibu-ibu masih ragu-ragu yaitu tindak lanjut pelatihan dan sosialisasi menjadi usaha yang nyata, sehingga ini sangat perlunya pendampingan lebih untuk menyakinkan Ibu-ibu PKK.

\section{Ucapan Terima Kasih}

Ucapan terima kasih penulis berikan kepada Pihak LPPM UPN Veteran Yogyakarta, karena telah memberikan kesempatan pada penulis untuk menuangkan tulisannya pada Jurnal Pengabdian Masyarakat ini.

\section{DAFTAR PUSTAKA}

Ahmadi Dkk. 2021. Pedoman Kuliah Pengabdian Masyarakat Daring Dari Rumah (KPM-DDR). Ponorogo: LP2M. 
Ahmad, Munawar. 2007. Asset Based Community Development (ABCD): Tipologi KKN Partisipatif UIN Sunan Kali Jaga, Jurnal Aplikasi Ilmu Agama, 8, (2). h.104-113.

Bhinardi, Ardito. 2017. Penanggulangan

Kemiskinan dan Pemberdayaan

Masyarakat. Yogyakarta:

DEEPUBLISH.

Malik, Hermen. 2019. Bangun Industri Desa Selamatkan Bangsa (Strategi Pembangunan Industri Desa di Kabupaten Kaur, Bengkulu). Bogor: PT. Penerbit IPB Press.

Meirejeki, I Nyoman. 2018. "Pengembangan Desa Wisata Melalui Peningkatan Kualitas SDM dan Pemanfaatan Bahan Baku Lokal di Desa Wisata Belimbing, Tabanan”, Jurnal Bhakti Persada Vol.4, No.1. H.31.

Prasetiyawan, Arian Agung.

Pemberdayaan Perempuan Melalui

Pendirian Kelompok Usaha Pitay Berbasis Social Preneur Guna Meningkatkan Kesejahteraan Masyarakat Kupang NTT, Jurnal Pengabdian Masyarakat, Vol.1, No.2, 2 July 2020, H. 107.

Suryandani,Wulan. Mahmudi , Aviv. 2018

- "Pengembangan Kualitas SDM dan Usaha Kelompok Pengrajin Tempe Desa Tahunan Kecamatan Sale
Kabupaten Rembang”, Prosiding Seminar Nasional Unimus, Vol.1. H.337.

Tallo, Amandus Jong Dkk. 2020.Membangun Peradaban Berbasis Wisata. Pekalongan: PT. Nasya Expanding Management.

Sudarmanto, Eko Dkk. 2020. Konsep Dasar Pengabdian Kepada Masyarakat (Pembangunan dan Pemberdayaan). Medan: Yayasan Kita Menulis.

Nugroho, Riant. 2021. Membangun Desa Wisata Bagian 2: Strategi Desa Wisata. Jakarta: Elex Media Koputindo. 